\title{
Effect of Deformation Parameters on Microstructural Evolution of GGG 40 Spheroidal Graphite Cast Iron Alloy
}

\author{
Marwan Faisal1, Eman El-Shenawy'2, Mohamed A. Taha1 \\ ${ }^{1}$ Faculty of Engineering, Ain-Shams University, Cairo, Egypt \\ ${ }^{2}$ Central Metallurgical Research and Development Institute (CMRDI), Cairo, Egypt \\ Email: marwan.faisal@eng.asu.edu.eg,dremanelshenawy@cmrdi.sci.eg,mohamed_taha@eng.asu.edu.eg
}

How to cite this paper: Faisal, M., ElShenawy, E. and Taha, M.A. (2019) Effect of Deformation Parameters on Microstructural Evolution of GGG 40 Spheroidal Graphite Cast Iron Alloy. Materials Sciences and Applications, 10, 433-450.

https://doi.org/10.4236/msa.2019.106032

Received: April 19, 2019

Accepted: June 2, 2019

Published: June 5, 2019

Copyright $\odot 2019$ by author(s) and Scientific Research Publishing Inc. This work is licensed under the Creative Commons Attribution International License (CC BY 4.0).

http://creativecommons.org/licenses/by/4.0/

\begin{abstract}
Studying the thermo-mechanical behavior of ductile iron is necessary to develop the rolling process for ductile iron sheet/strip production, thus, extending its application by replacing steel in several fields such as machine casing, constructional applications, etc. In order to predict the safe rolling conditions for producing sheets and strips, the thermo-mechanical behavior of a ductile iron alloy, with CE of 4.48, is studied by physical simulation of hot rolling process using Gleeble-3500 simulator. The test was conducted on specimens at a range of deformation temperatures from $800^{\circ} \mathrm{C}$ to $950^{\circ} \mathrm{C}$ while three different strain rates; namely $0.05,0.1$ and $0.5 \mathrm{~s}^{-1}$ were used. The results obtained, show minimum values of flow stresses at $850^{\circ} \mathrm{C}$. By increasing the deformation temperature up to $900^{\circ} \mathrm{C}$, the flow stresses increased to reach maximum values, beyond which the flow stress decreased again. A remarkable dynamic recrystallization is observed at the deformation temperatures of $850^{\circ} \mathrm{C}$ and $800^{\circ} \mathrm{C}$ with applied strain rates of 0.05 and $0.1 \mathrm{~s}^{-1}$. Gleeble test results are correlated with microstructure observations on samples quenched at their deformation temperatures, where the changes in structure and graphite morphology are reported. The deformation process at high temperatures namely $950^{\circ} \mathrm{C}$ and $900^{\circ} \mathrm{C}$ result in changing the graphite shape from a spheroidal-like to a saucer-like shape. However, by decreasing the deformation temperature to $850^{\circ} \mathrm{C}$ as well as $800^{\circ} \mathrm{C}$, graphite with lamellar shape is observed. As a conclusion, ductile iron could be successfully deformed without cracking at the applied conditions.
\end{abstract}

\section{Keywords}

Ductile Iron, Thermo-Mechanical Behavior, Gleeble-3500, Physical Simulation, Graphite Morphology 


\section{Introduction}

Ductile iron (DI) is an iron-carbon alloy consisting of graphite nodules embedded in a steel matrix [1]. Despite the metallurgical similarity between steel and ductile iron [2] [3], a different response to heat treatment is detected due to the high content of carbon and silicon in ductile iron. The graphite nodules or spheroids act as a carbon sink or a carbon source in ductile iron, thus playing a significant role in the treatment process [3] [4]. Moreover, ductile iron compelled a wide recognition as an economical choice for replacing steel parts for its high toughness [5]. It is so far used in bearing journals and automotive components, for its relatively lower cost than steel, high cast-ability and outstanding wear resistance [6].

Ductile iron has advantages due to the additional characteristics that can be customized for applications requiring corrosion resistance, low thermal expansions, vibration damping and lubricating surface [7] [8]. These properties are required in strips and sheets for several applications namely; machine casing and constructional applications. Thus, replacing steel sheets by ductile iron sheets is proposed as an interesting idea. Although ductile iron exhibits high ductility for the forming process, only a few researchers [9] [10] [11] [12] investigated the formability and the rolling behavior of ductile iron.

Samuel [13] investigated the phase transformation kinetics in ductile iron by using a Gleeble machine that was to estimate the CCT curve for 65-45-12 ductile iron. Moreover, Zaho[14] [15] [16] applied a new severe plastic deformation process on ductile iron and studied the graphite morphology after applying a hot compression test on ductile iron alloy. Recently, the hot deformation behavior and the graphite morphology of ductile iron were investigated using the physical simulation technique [6] [17] [18]. Additionally, the microstructural changes in pearlitic-ferritic matrix were reported by increasing the degree of hot plastic deformation [19] [20]. Furthermore, Soliman [21] studied the transformation kinetics of thermo-mechanically processed ductile iron alloys.

In the current work, thermo-mechanical behavior of a ductile iron alloy with carbon Equivalence (CE) of $4.48 \mathrm{wt} \%$ was studied by using Gleeble- 3500 physical simulator. By the aid of the physical simulation process, thermo-mechanical behavior and phase transformations during this process were highlighted. The data obtained from the physical simulation technique will be used in the rolling process to produce sheets and/or strips of ductile iron.

\section{Experimental Procedures}

\subsection{Objective and Methodology}

The objective of this research is to study the hot deformation behavior of ductile iron at different temperatures and strain rates. The methodology includes;

1) Dilation test in order to determine the critical phase transformation temperatures,

2) Heat treatment experiments for phase identification before applying the 
deformation process,

3) Physical simulation using Gleeble- 3500 machine for studying the thermo-mechanical behavior of ductile iron at different temperatures and strain rates.

\subsection{Material Stock}

The chemical composition of the ductile iron alloy used in this work is given in Table 1, where the carbon Equivalence (CE) of the alloy is 4.48. Specimens for dilation test, heat treatment experiments, and thermo-mechanical processing were machined under cooling conditions.

\subsection{Dilation Test}

The objective of the dilation test was to determine the critical phase transformation temperatures during heating (Ac11 and Ac12). The experiments are carried out on a cylindrical specimen with $4 \mathrm{~mm}$ in diameter and $30 \mathrm{~mm}$ in length by using differential dilatometer L76. Sheathed S-type thermocouple was spot welded on the specimen surface. Afterward, the specimen was placed horizontally between two Quartz stamps. The dilation test involved heating the specimen to a temperature of $950^{\circ} \mathrm{C}$ with a heating rate of $30^{\circ} \mathrm{C} / \mathrm{min}$. Afterward, the specimen was soaked for 20 minutes and followed by air cooling to room temperature.

\subsection{Heat Treatment Experiments}

After determining the phase transformation temperatures (Ac11 and Ac12), four heat treatment schedules were applied on the ductile iron cubic specimens of 10 $\times 10 \times 10 \mathrm{~mm}$. The schedules involved heating the specimens (H-I, H-II, H-III and $\mathrm{H}-\mathrm{IV}$ ) in a muffle furnace to four different temperatures namely; $950^{\circ} \mathrm{C}$, $900^{\circ} \mathrm{C}, 850^{\circ} \mathrm{C}$, and $800^{\circ} \mathrm{C}$ respectively. Subsequently, the specimens were soaked for 20 minutes and followed by water-quenching to room temperature. These cycles were applied in order to identify the phases formed at the mentioned temperatures.

\subsection{Physical Simulation Using Gleeble-3500}

The hot deformation behavior of the ductile iron was studied using a computer servo-controlled Gleeble-3500 machine, which was adapted to apply uniaxial compression test. In accordance with that machine, the test was performed on cylindrical specimens with $10 \mathrm{~mm}$ in diameter and $120 \mathrm{~mm}$ long, as shown in Figure 1. The axial compression was confined to the central specimen length of $30 \mathrm{~mm}$, due to test specimen fixation as shown in Figure 2. K-type thermo

Table 1. Chemical composition of Ductile Iron used in this work.

\begin{tabular}{cccccc}
\hline Element & $\mathrm{C}$ & $\mathrm{Si}$ & $\mathrm{Mn}$ & $\mathrm{Fe}$ & $\mathrm{CE}$ \\
\hline wt\% & 3.54 & 2.87 & 0.212 & 93.71 & 4.48 \\
\hline
\end{tabular}




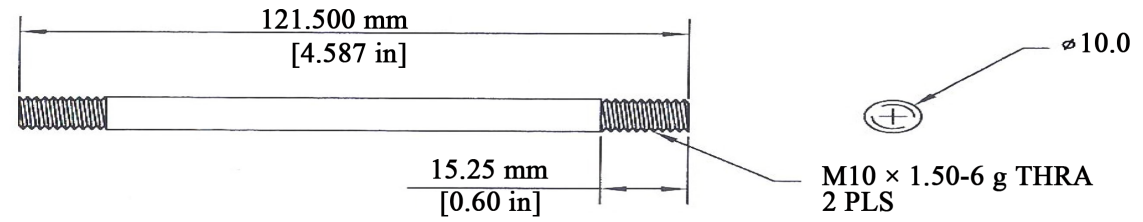

Figure 1. Gleeble Test specimen used in the physical simulation.
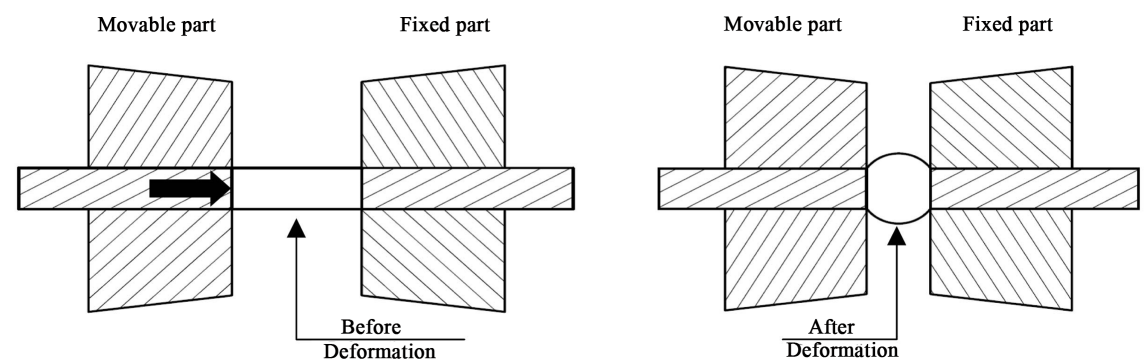

Figure 2. Gleeble test specimen before and after deformation.

couple wire was spot-welded in the middle of the specimen in order to measure and control the specimen's temperature. More details about the test are found elsewhere [22] [23].

After identifying the phases evolved due to the heat treatment experiment, four thermo-mechanical schedules were designed in order to study the hot deformation behavior of the ductile iron alloy at four different temperatures namely; $950^{\circ} \mathrm{C}, 900^{\circ} \mathrm{C}, 850^{\circ} \mathrm{C}$, and $800^{\circ} \mathrm{C}$ with three different applied strain rates of $0.05,0.1$ and $0.5 \mathrm{~s}^{-1}$. The schedules involved heating the specimens with a heating rate of $10^{\circ} \mathrm{C} / \mathrm{s}$ to the desired deformation temperatures (T) and keeping for 20 minutes (see Table 2) to ensure structure homogenization and allow grain growth. Afterward, 39\% deformation was applied on the specimens which are equivalent to a true strain of $(-0.5 \mathrm{~mm} / \mathrm{mm})$ with three different applied strain rates $(\dot{\varepsilon})$ of $0.05,0.1$ and $0.5 \mathrm{~s}^{-1}$ and followed by quenching to room temperature with cooling rate of $50^{\circ} \mathrm{C} / \mathrm{s}$, Figure 3 .

\subsection{Microstructure Investigation}

In order to investigate the microstructural constituents, specimens were prepared by mechanical grinding followed by polishing up to $1 \mu \mathrm{m}$-grade diamond paste. The microstructures were examined by the aid of a light optical microscope (LOM) after etching with Picral and/or 2\% Nital. For superior microstructural analysis and phase identification, the specimens were investigated by SEM and EDX analysis.

\section{Results and Discussion}

\subsection{Dilation Results}

Phase transformations are indicated by the deviation from linearity of (temperature-relative change in length) curve upon heating and cooling the specimens, as the structure changes. Ac11 and Ac12 critical transformation temperatures 


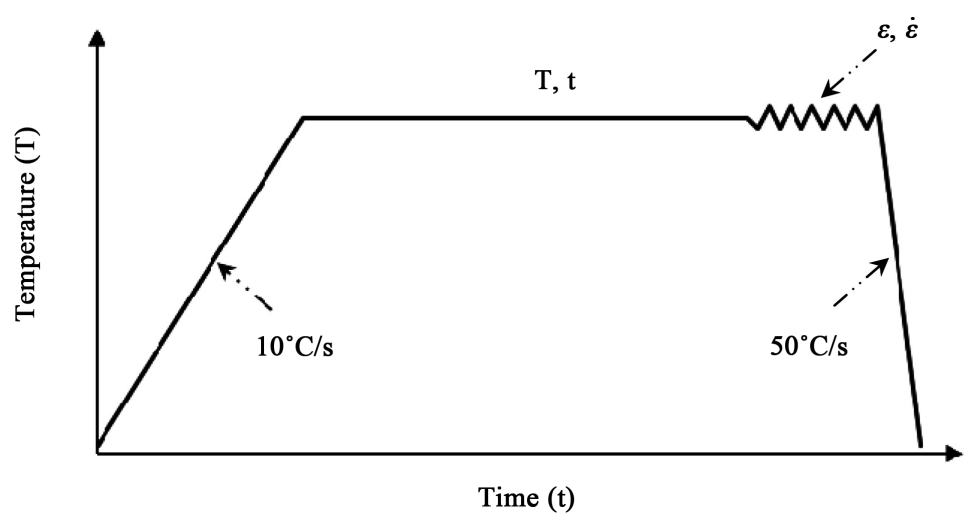

Figure 3. Schematic presentation of deformation schedules applied to ductile iron specimens.

Table 2. Deformation schedules of ductile iron specimens.

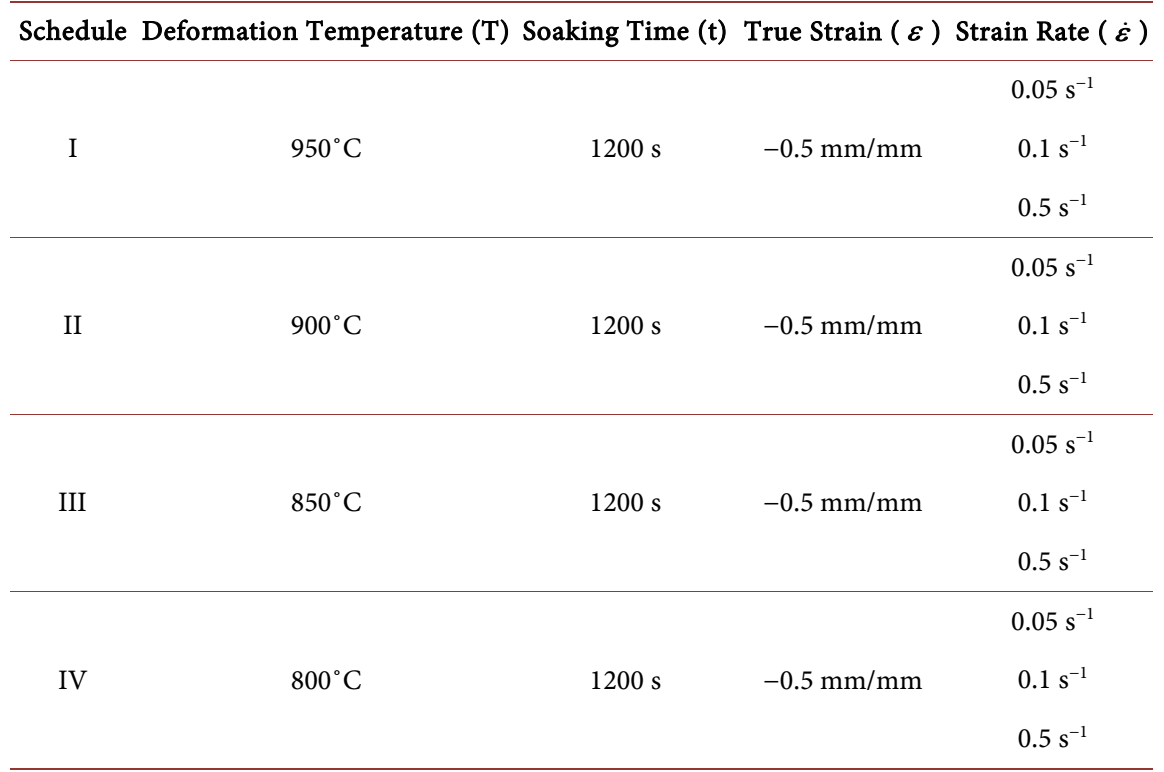

are determined from the (temperature-relative change in length) curve, Figure 4, during the heating of the specimen. Due to the thermal expansion, the specimen's length increases linearly upon heating. The austenite is formed at the interface of ferrite-cementite within the pearlite. The decomposition of the cementite (found in pearlite) into austenite began at $792^{\circ} \mathrm{C}$ as a non-linear increase is observed. Due to the decomposition of compacted cementite which has an orthorhombic structure, carbon atoms diffuse from the cementite resulting in a non-linear increase in the length of the specimen to $825^{\circ} \mathrm{C}$. Moreover, pro-eutectoid ferrite transformation to austenite is accompanied by a non-linear decrease in length up to a temperature of $867^{\circ} \mathrm{C}$, as an open structure (BCC-ferrite) transformed to closed packed structure (FCC-austenite). Further heating resulted in an increase in the specimen's length, indicating the diffusion of carbon atoms from graphite nodules into the austenitic matrix [24] and/or thermal expansion of the specimen. 


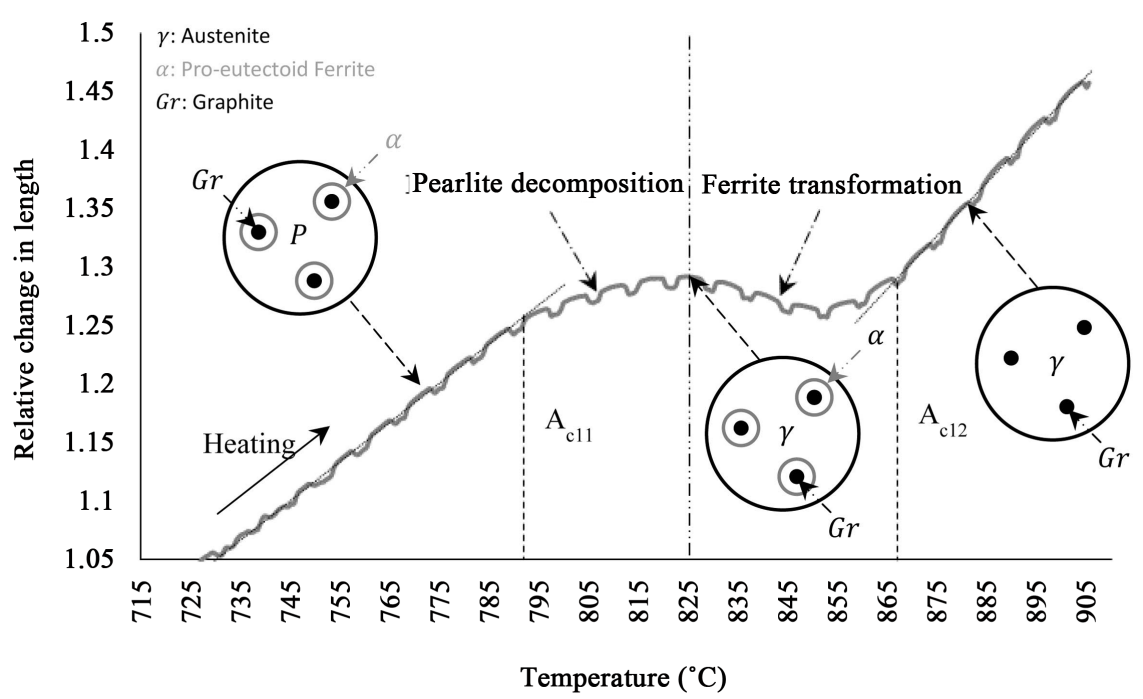

Figure 4. Enlarged part from (Relative change in length-Temperature) during the heating of ductile iron specimen.

\subsection{Heat Treatment Results}

The as-cast specimen which consists of the pearlitic-ferritic matrix is given in Figure 5(a). The observed microstructures of H-I, H-II, and H-III specimens aregraphite nodules embedded in martensitic colonies, Figures 5(b)-(d) respectively. Thus, the austenite phase is formed at the mentioned temperatures before quenching the specimens to room temperatures. While in H-IV specimen, Figure 5(e), the obtained microstructure is martensite and pro-eutectoid ferrite surrounding the graphite nodules. That is due to the heating of H-IV specimen in the inter-critical annealing region which results in the growth of the pro-eutectoid ferrite as well as the formation of the austenite. Later, the austenite is transformed to martensite after quenching H-IV specimen to room temperature.

\subsection{Physical Simulation Results}

\subsubsection{Flow Stresses during the Thermo-Mechanical Processing}

The effect of the deformation temperatures on the mechanical behavior of the ductile iron alloy with applied strain rates of $0.05,0.1$ and $0.5 \mathrm{~s}^{-1}$ is shown in Figures 6(a)-(c) respectively. The minimum values of flow stresses are observed during the deformation of the ductile iron at $850^{\circ} \mathrm{C}$. However, the flow stresses increased to reach the maximum values by increasing the deformation temperature up to $900^{\circ} \mathrm{C}$, beyond which the flow stresses decrease again. It is clearly observed that the thermo-mechanical behavior of the ductile iron alloy is nearly the same as the deformation temperatures $850^{\circ} \mathrm{C}$ and $800^{\circ} \mathrm{C}$. Moreover, a remarkable dynamic recrystallization is observed at deformation temperatures of $850^{\circ} \mathrm{C}$ and $800^{\circ} \mathrm{C}$ with applied strain rates of 0.05 and $0.1 \mathrm{~s}^{-1}$.

Figure 7 shows the effect of the applied strain rate on the thermo-mechanical behavior of the ductile iron alloy. It was noticed that the flow stress is directly 

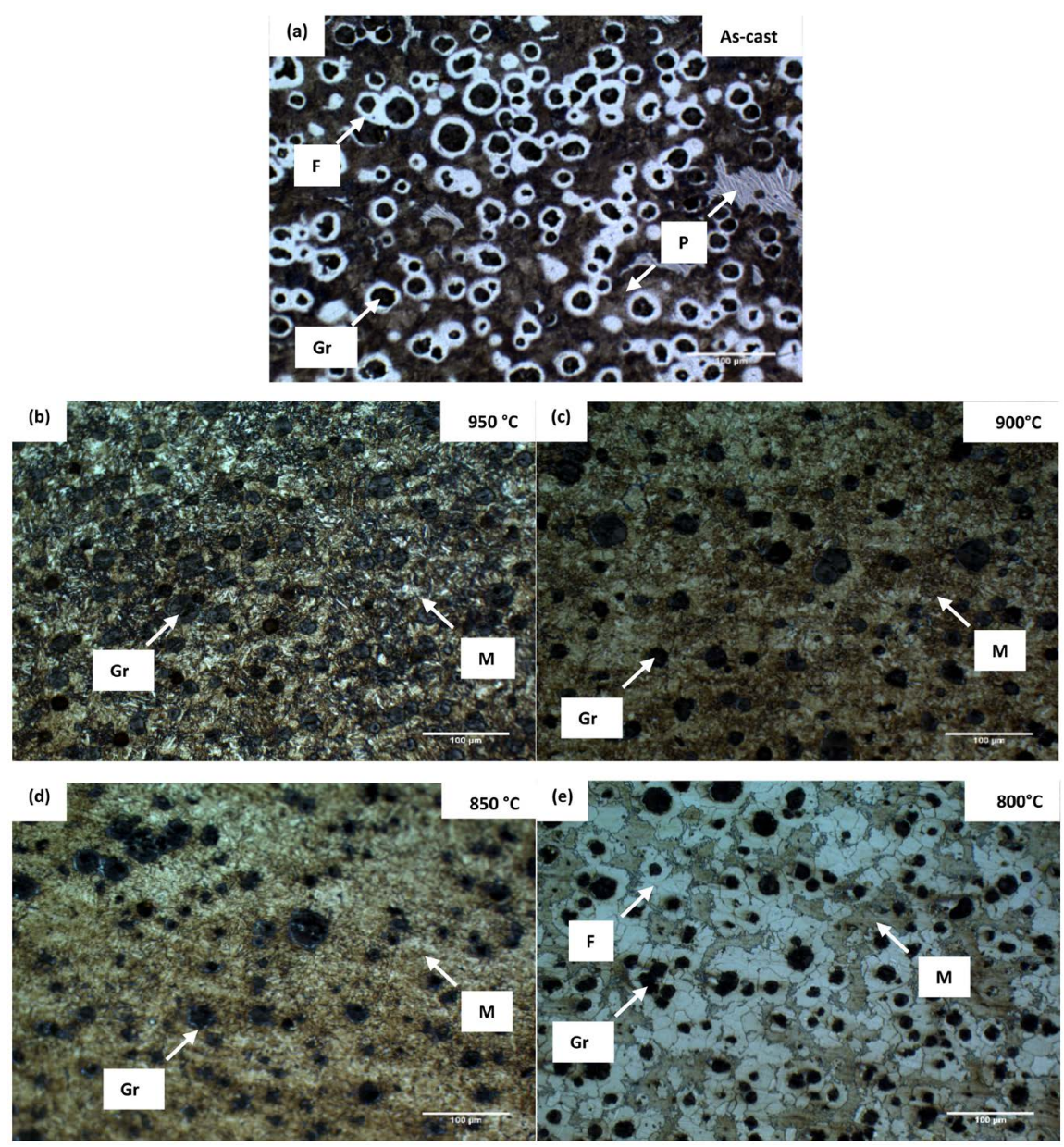

Figure 5. Microstructures of as-cast, H-I, H-II, H-III and H-IV specimens respectively.

proportional to the strain rate, as by increasing the strain rate, the flow stress values of the alloy increase at the same deformation temperature. Anelasticplastic flow behavior is observed by deforming the ductile iron alloy at $950^{\circ} \mathrm{C}$ and $900^{\circ} \mathrm{C}$ with applied strain rates of 0.05 and $0.1 \mathrm{~s}^{-1}$. While by increasing the strain rate to $0.5 \mathrm{~s}^{-1}$, a strain hardening behavior is detected. In contrast, a dynamic recrystallization occurred by applying strain rates of 0.05 and $0.1 \mathrm{~s}^{-1}$ at deformation temperatures of $850^{\circ} \mathrm{C}$ and $800^{\circ} \mathrm{C}$.

\subsubsection{Microstructure Evolution}

The microstructure of deformed specimens, after quenching to room temperature is observed in directions perpendicular and parallel to the applied force, as shown in Figure 8. At all strain rates applied $\left(0.05,0.1\right.$, and $\left.0.5 \mathrm{~s}^{-1}\right)$, varying the deformation temperature cause variation in the microstructure. At a deformation temperature of $950^{\circ} \mathrm{C}$, a fully martensitic matrix surrounding the graphite nodules is observed in the quenched specimens. While by decreasing the deformation temperature to $900^{\circ} \mathrm{C}$, graphite nodules embedded in a martensitic-pearlitic matrix is detected. Both indicate a completely austenitic matrix at the mentioned temperatures after the deformation process, i.e. the austenite phase 


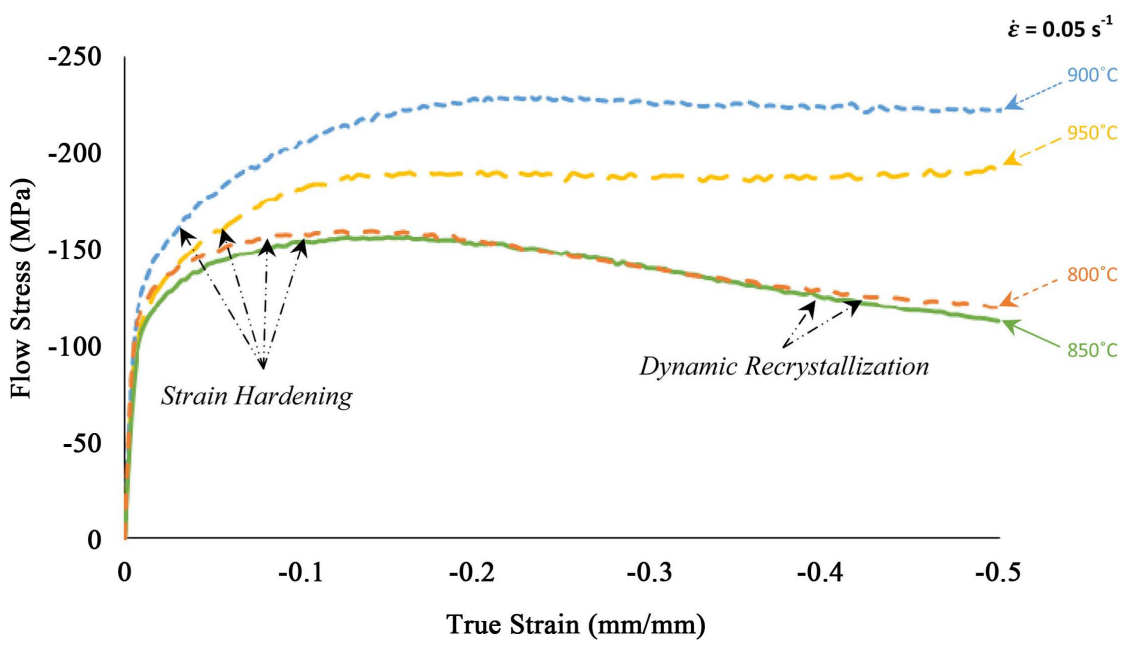

(a)

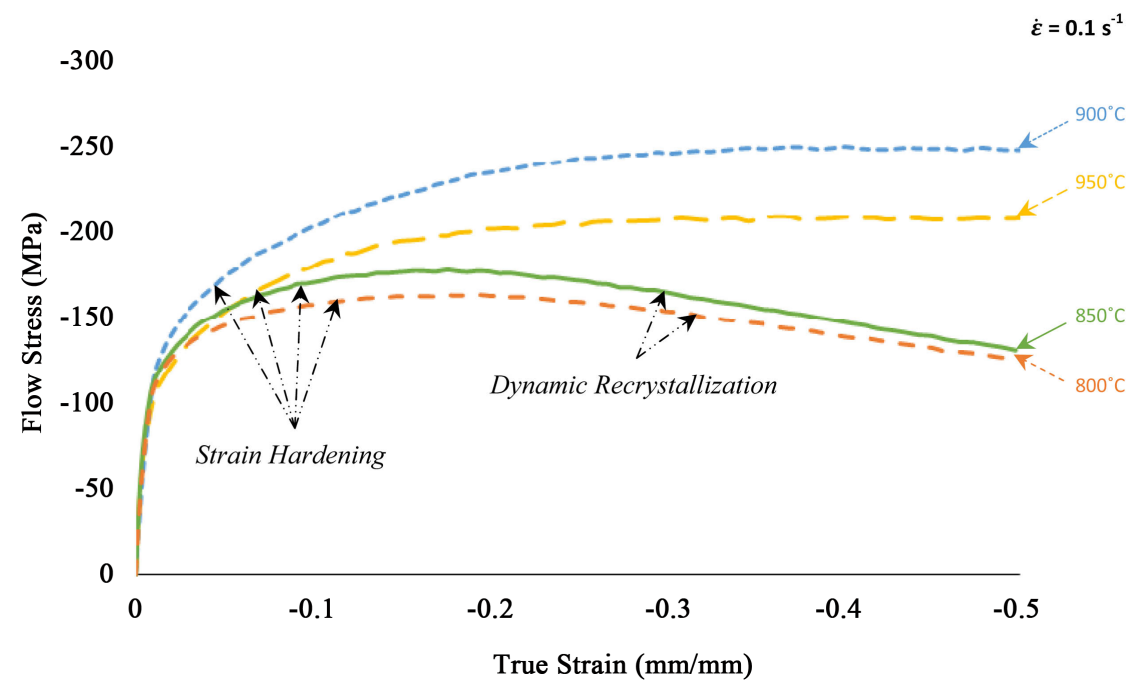

(b)

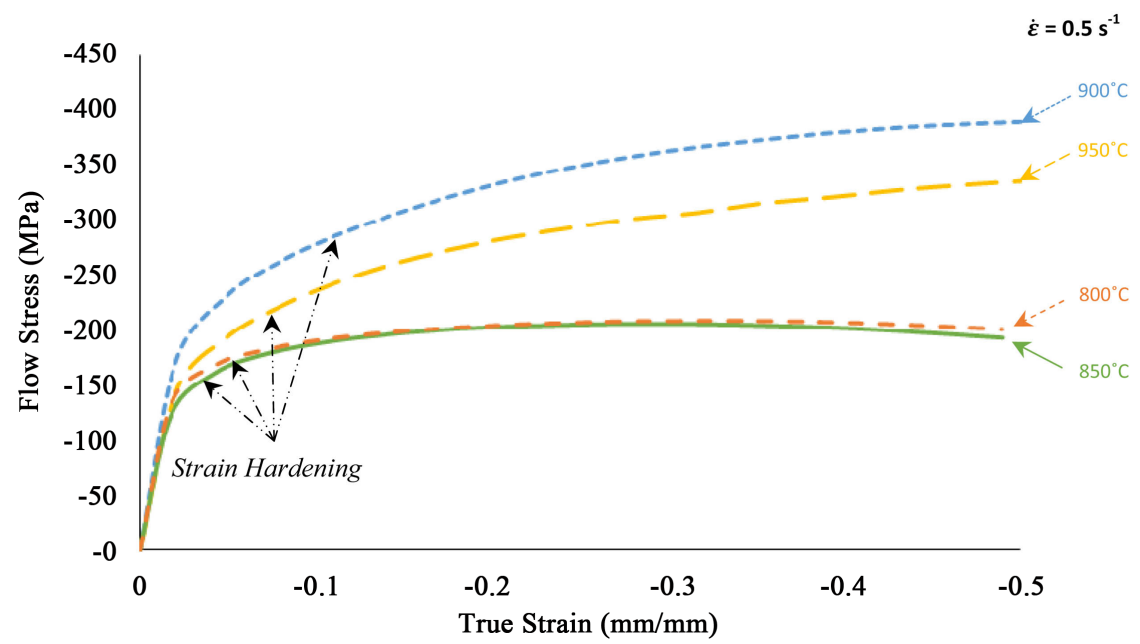

(c)

Figure 6. Thermo-mechanical behavior of the ductile iron alloy at applied strain rates of (a) $0.05 \mathrm{~s}^{-1}$; (b) $0.1 \mathrm{~s}^{-1}$ and (c) $0.5 \mathrm{~s}^{-1}$. 


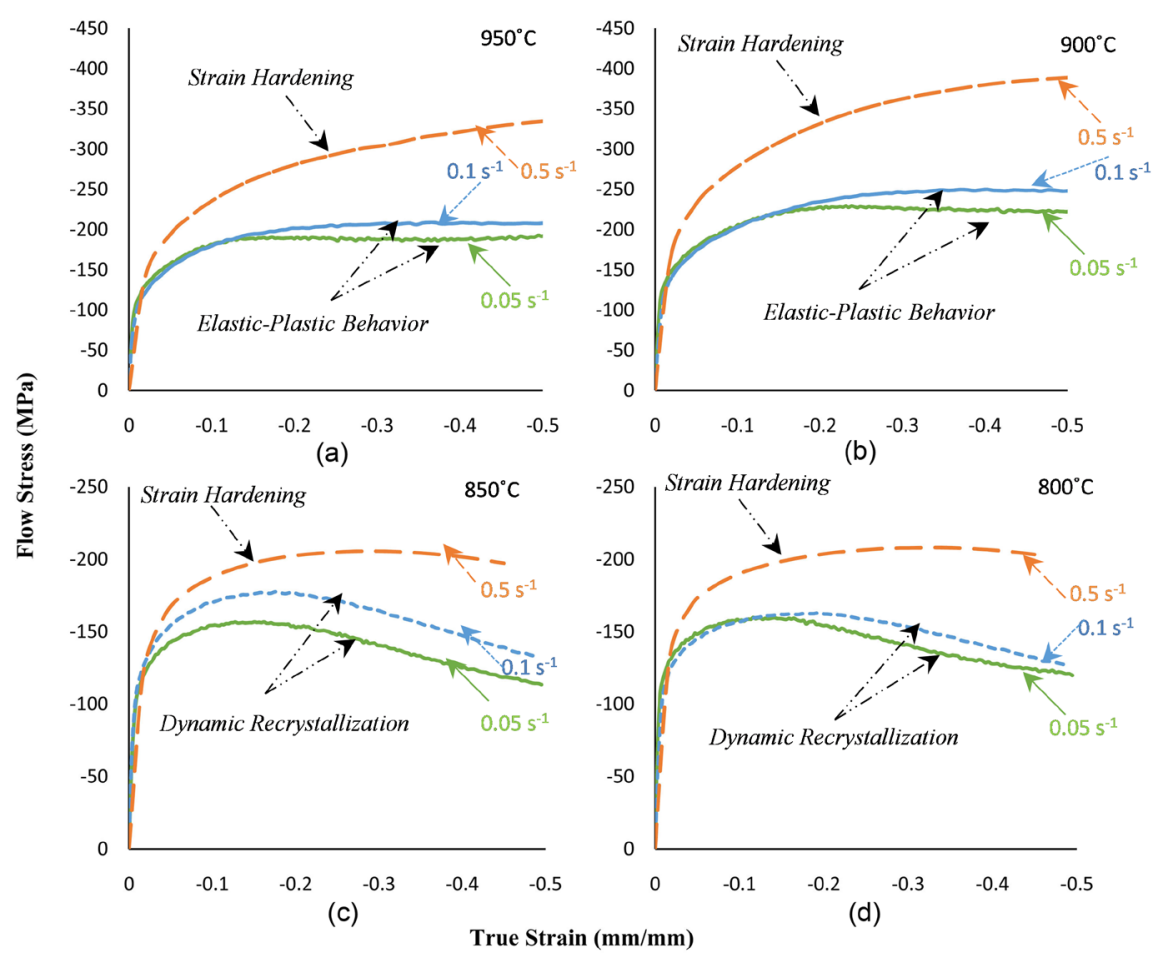

Figure 7. The effect of the applied strain rates on the thermo-mechanical behavior of the ductile iron alloy at deformation temperatures of (a) $950^{\circ} \mathrm{C}$; (b) $900^{\circ} \mathrm{C}$; (c) $850^{\circ} \mathrm{C}$ and (d) $800^{\circ} \mathrm{C}$.

formed by heating at such temperatures above Ac12 did not change upon deformation. The carbon content in the austenitic matrix decreases by decreasing the temperature, [25] i.e. at the deformation temperature of $900^{\circ} \mathrm{C}$, the amount of dissolved carbon in the austenitic matrix is less than that at $950^{\circ} \mathrm{C}$. Thus upon quenching the specimens, the pearlite phase is formed around the graphite nodules, due to the diffusion of carbon atoms from the austenite phase to the graphite nodules [26].

At $850^{\circ} \mathrm{C}$ and temperature below Ac12 of $800^{\circ} \mathrm{C}$, a similar microstructure of pearlite and pro-eutectoid ferrite surrounding the graphite nodules are observed in the deformed specimens, indicating austenitic-ferritic matrix prior to quenching. Although the revealed microstructure before deforming the specimens at $850^{\circ} \mathrm{C}$ is an austenitic matrix, the microstructure of the deformed specimens at the same temperature is an austenitic-ferritic matrix. Low carbon content in the austenite resulted in pearlite and/or pro-eutectoid ferrite formation. In addition, pro-eutectoid ferrite is found around the graphite nodules and in regions far from the graphite nodules. SEM on the deformed specimen at $850^{\circ} \mathrm{C}$ and strain rate of $0.05 \mathrm{~s}^{-1}$, reveal fine pro-eutectoid ferrite surrounding the graphite nodules, while EDX analysis indicates high silicon content of 3.15 wt $\% \mathrm{Si}$ in this phase. Within the matrix and far from the graphite nodules, fine pro-eutectoid ferrite grains are also observed with lower Si content of $2.72 \mathrm{wt} \%$ as shown in Figure 9. At a lower deformation temperature of $800^{\circ} \mathrm{C}$ and strain 


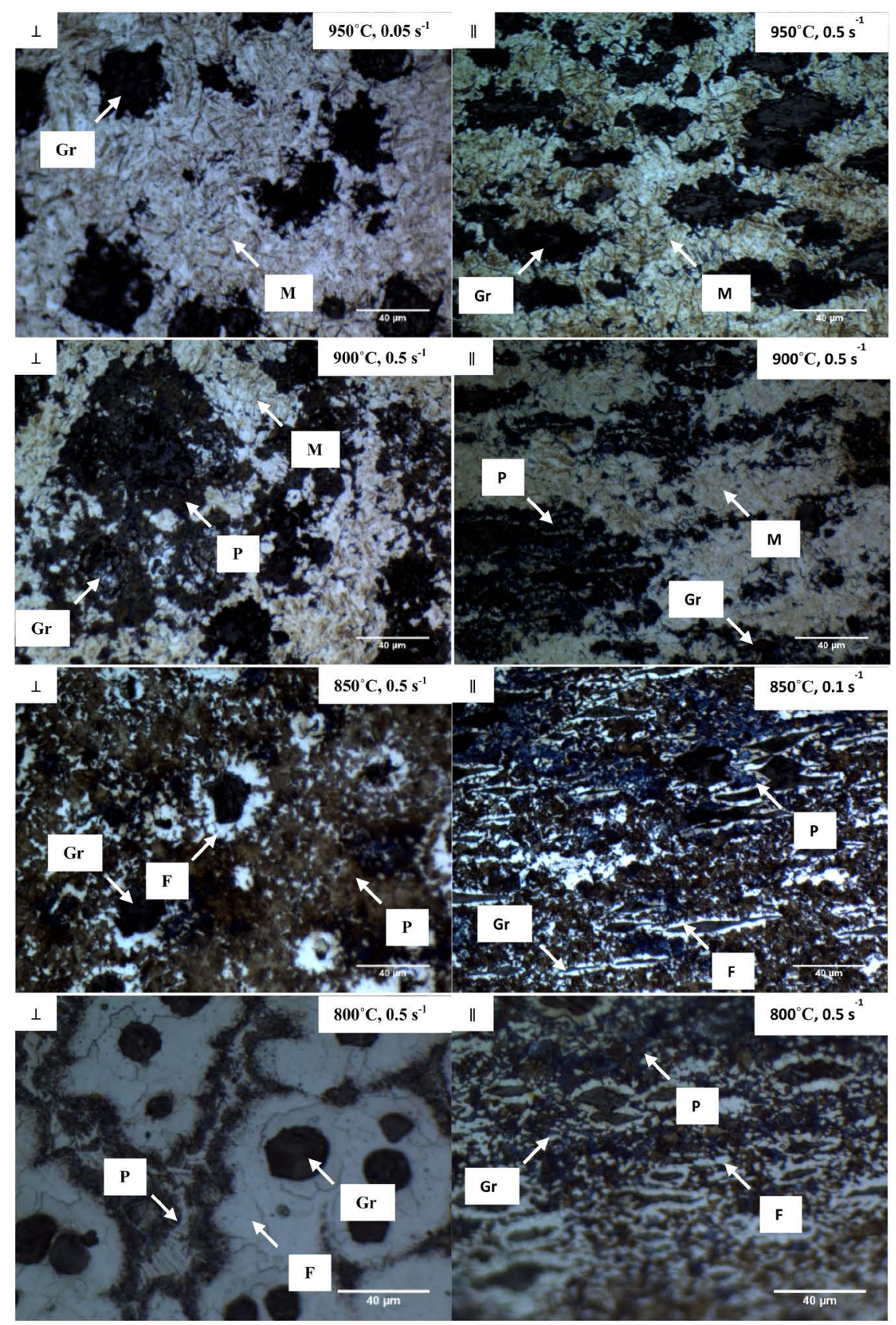

Figure 8. The revealed microstructure of the deformed specimens at different conditions in direction perpendicular $(\perp) \&$ parallel $(/ /)$ to the applied force.

rate of $0.05 \mathrm{~s}^{-1}$, a higher Si content of $3.33 \mathrm{wt} \%$ was detected in the pro-eutectoid ferrite within the matrix, Figure 10.

The pro-eutectoid ferrite formation and/or growth-which is detected at $850^{\circ} \mathrm{C}$ and $800^{\circ} \mathrm{C}-$ contributes in increasing the graphite volume fraction as the carbon atoms diffuse from the austenitic matrix to the graphite nodules during the pro-eutectoid ferrite formation. At any deformation temperature, no significant effect on the graphite morphology is observed through varying the applied strain rates. However, a pronounced variation of graphite volume fraction is 

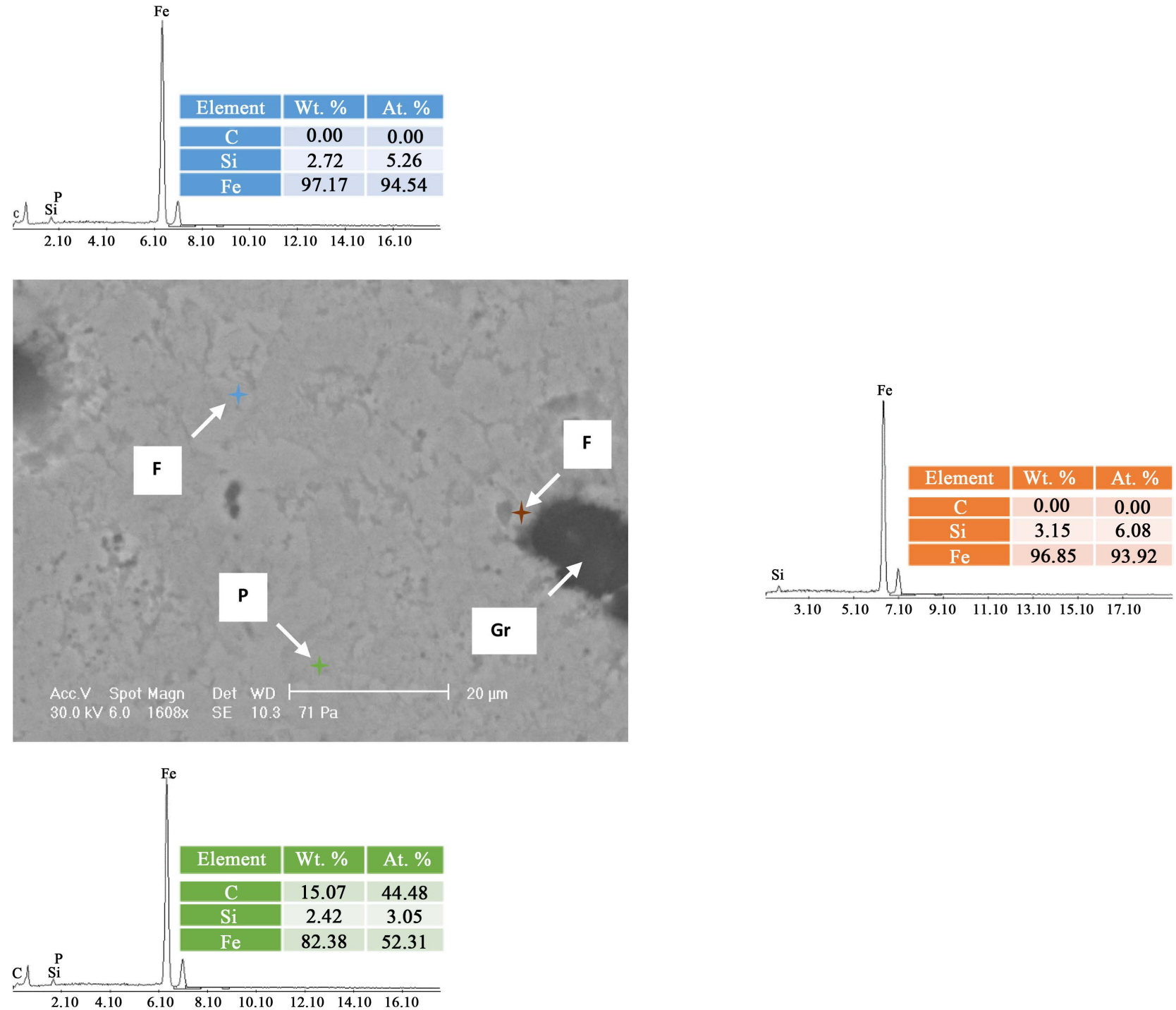

Figure 9. SEM and EDX analysis of the deformed specimen at $850^{\circ} \mathrm{C}$ with an applied strain rate of $0.05 \mathrm{~s}^{-1}$.

observed by varying deformation temperature, Figure 11. With decreasing the deformation temperature, the graphite volume fraction increases as more graphite has been formed.

\subsubsection{Thermo-Mechanical Behavior and Microstructure}

Figure 12 schematically correlates the microstructure with the thermo-mechanical behavior of the ductile iron specimens at different temperatures with an applied strain rate of $0.05 \mathrm{~s}^{-1}$. By decreasing the deformation temperature from $950^{\circ} \mathrm{C}$ to $900^{\circ} \mathrm{C}$, the flow stress values increase at the same applied strain rate. The microstructure of the ductile iron prior to the deformation process at the mentioned temperatures is graphite nodules embedded in an austenitic matrix. Thus, deforming the ductile iron at $950^{\circ} \mathrm{C}$ and $900^{\circ} \mathrm{C}$ is mainly deforming the austenite phase (single phase deformation).

Although the microstructure of the ductile iron revealed an austenitic matrix 

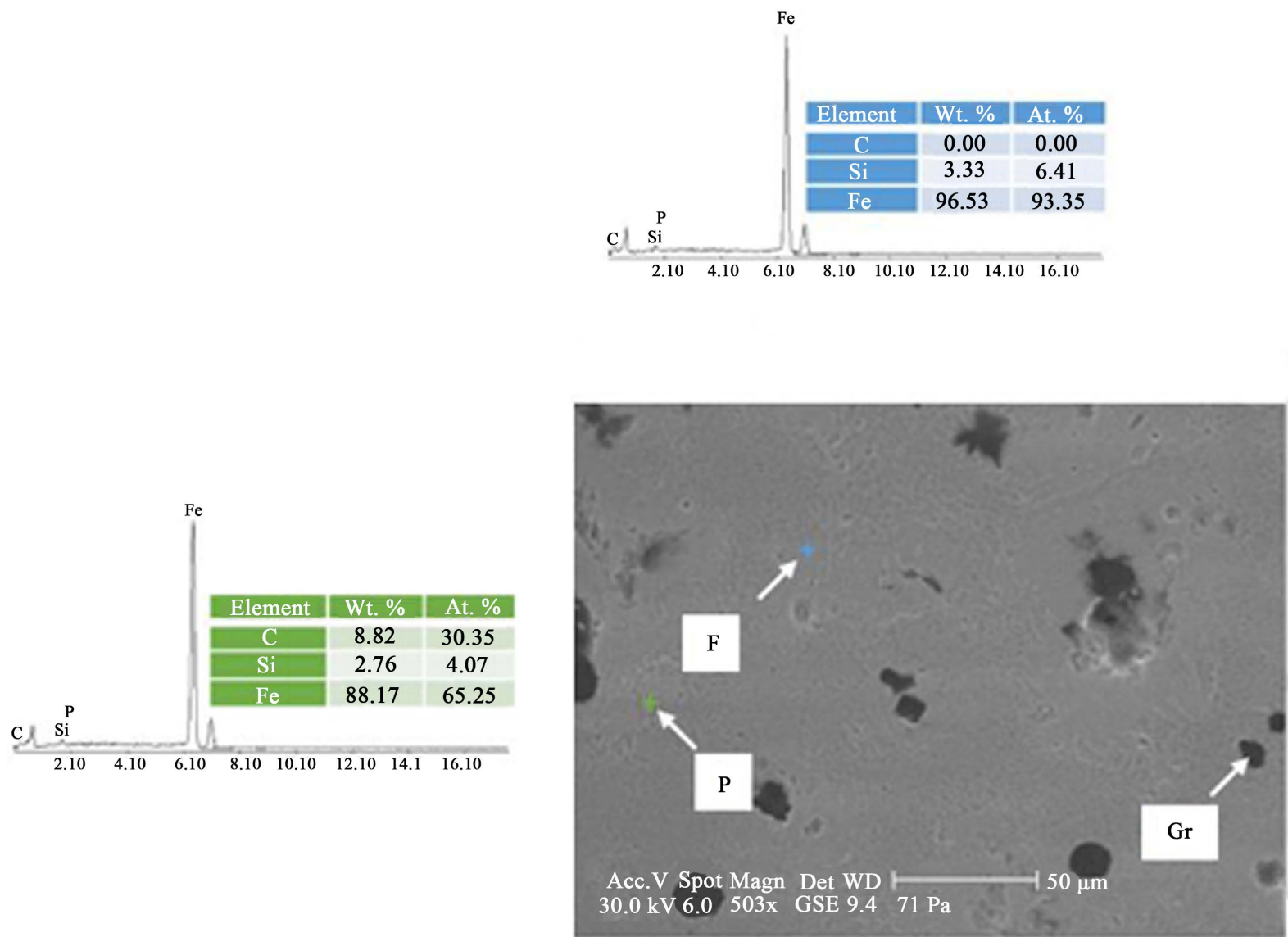

Figure 10. SEM and EDX analysis of the deformed specimen at $800^{\circ} \mathrm{C}$ with an applied strain rate of $0.05 \mathrm{~s}^{-1}$.

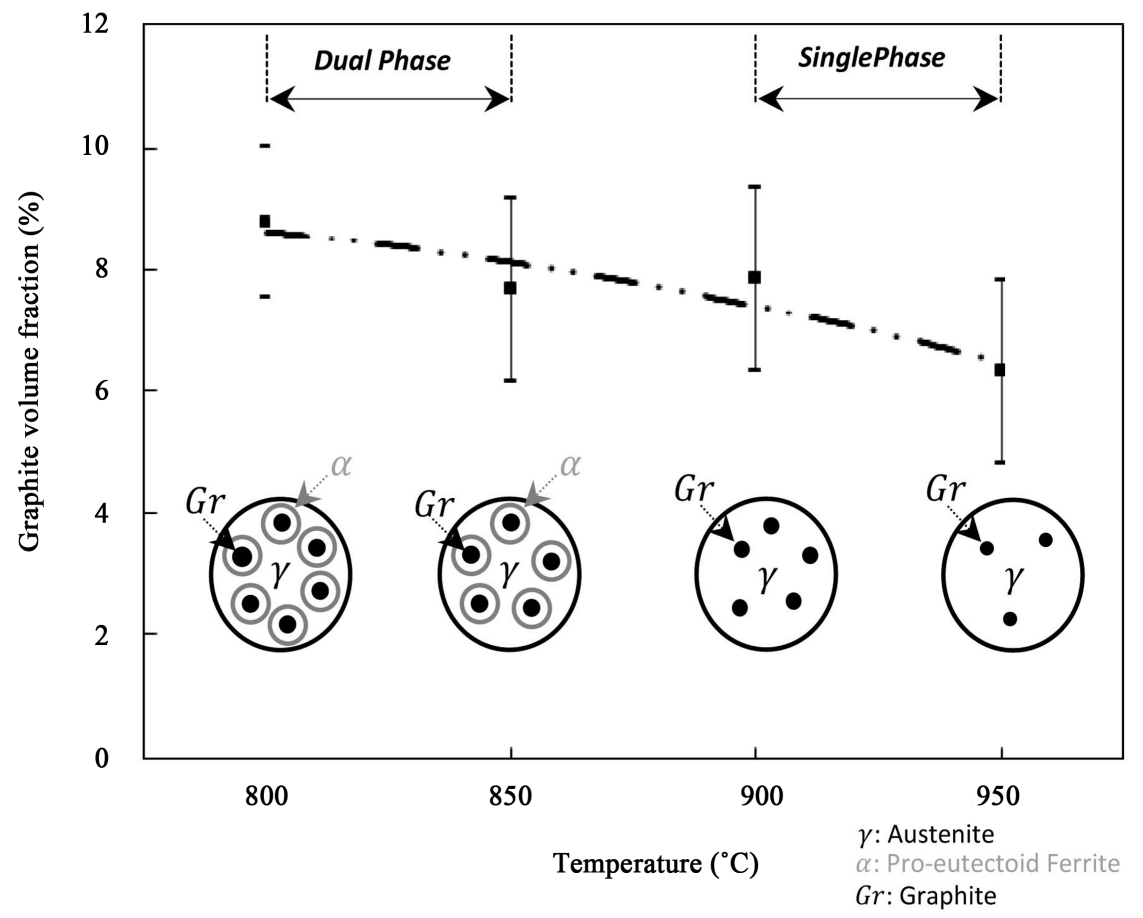

Figure 11. Dependence of the graphite volume fraction on the deformation temperatures. 


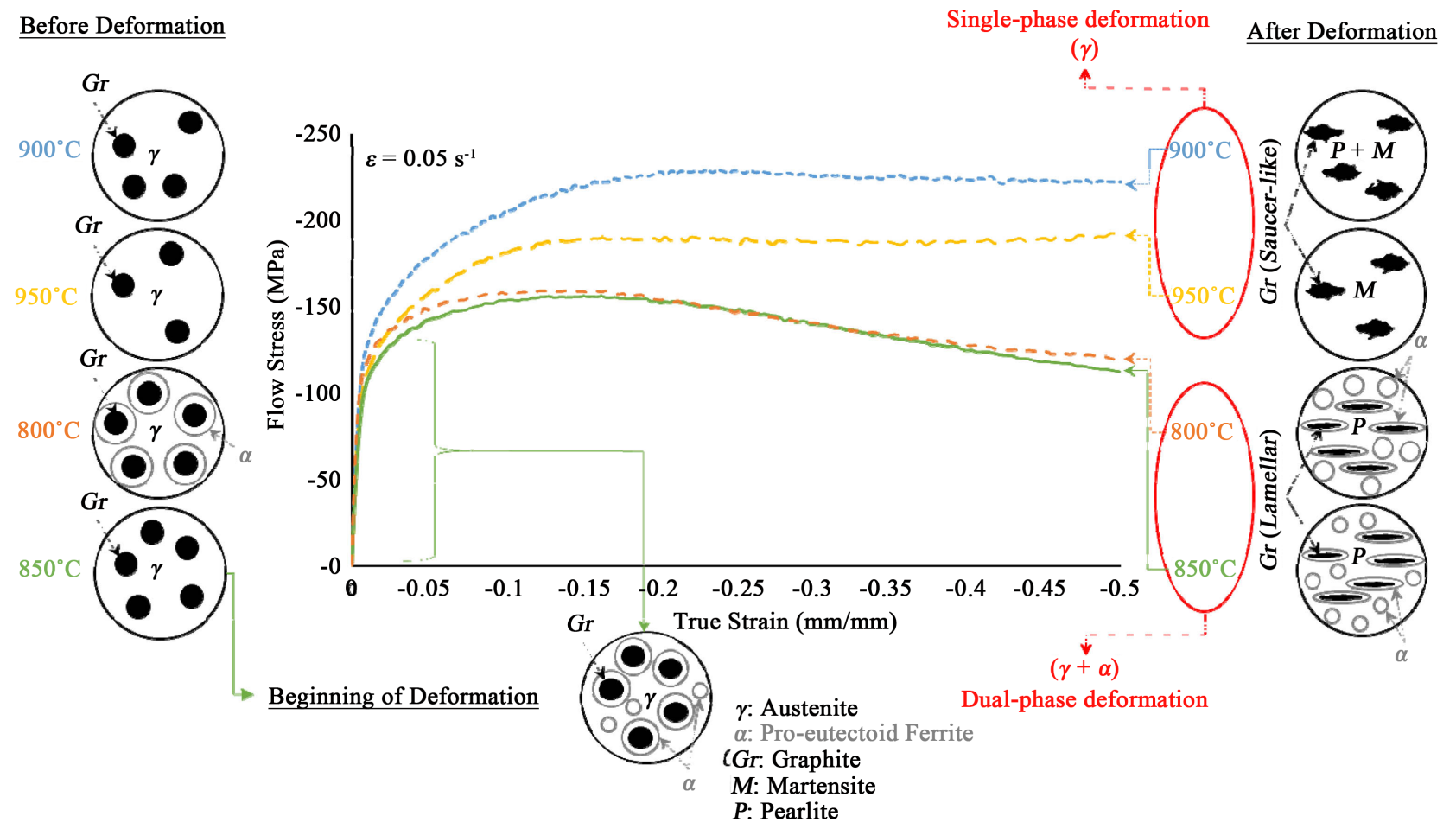

Figure 12. Flow Stress-True strain curves obtained by deforming the ductile iron at an applied strain rate of $0.05 \mathrm{~s}^{-1}$, where the schematic presentation of the evolved microstructures before and after deformation were superimposed.

prior to deformation at $850^{\circ} \mathrm{C}$, the arose flow stresses at $850^{\circ} \mathrm{C}$ are lower than that at $900^{\circ} \mathrm{C}$ and $950^{\circ} \mathrm{C}$. Isothermal soaking for the ductile iron at $850^{\circ} \mathrm{C}$ is just above the critical austenite transformation temperature namely; Ac12. Consequently, at the early stage of the deformation process, austenite is transformed to pro-eutectoid ferrite surrounding the graphite nodules and within the high silicon concentration regions. Hence, the pro-eutectoid ferrite is introduced and stabilized by the aid of the silicon atoms. That results in decreasing the volume fraction of the austenite as well as decreasing the flow stresses. Therefore, deforming the ductile iron at $850^{\circ} \mathrm{C}$ is mainly deforming dualphase namely; austenite and pro-eutectoid ferritephases. It is observed that the thermo-mechanical behavior of the ductile iron at $800^{\circ} \mathrm{C}$ and $850^{\circ} \mathrm{C}$ is almost the same, as deforming the ductile iron at $800^{\circ} \mathrm{C}$ is also deforming a dual phase matrix of austenite and pro-eutectoid ferrite. Thus, introducing the soft pro-eutectoid ferrite to the austenitic matrix which simultaneously increases the graphite volume fraction results in decreasing the stress required to deform the ductile iron alloy. In a previous work, Qi [5] investigated the hot deformation behavior of ductile iron with $\mathrm{CE}=4.8$ at a range of temperatures between $600^{\circ} \mathrm{C}$ and $950^{\circ} \mathrm{C}$ with a high strain rate of $10 \mathrm{~s}^{-1}$. The stress-strain curves obtained from his work showed stress values at the deformation temperature of $750^{\circ} \mathrm{C}$ lower than that of $800^{\circ} \mathrm{C}$. Qi claimed that dynamic softening occurred upon deforming the alloy at $750^{\circ} \mathrm{C}$. 
Additionally, a remarkable dynamic recrystallization is observed upon deforming the ductile iron at $850^{\circ} \mathrm{C}$ and $800^{\circ} \mathrm{C}$ with applied strain rates of 0.05 and $0.1 \mathrm{~s}^{-1}$. At the early stages of the deformation process, pro-eutectoid ferrite is introduced and/or existed around the graphite nodules at the mentioned temperatures. Moreover, the high amount of silicon is found at the interface of the graphite nodules [25]. Hence, a barrier of high silicon content in the pro-eutectoid ferrite is formed and restricted the role of the graphite nodules as a carbon sink. Therefore, the austenite phase is isolated by the stabilized pro-eutectoid ferrite. Nevertheless, the carbon atoms favor diffusing from the austenite phase as the temperature decreased upon further deformation. However, the formed barrier hindered and/or dropped the diffusion rate of the carbon atoms to the graphite nodules. In addition, the increase of the dislocation densities by further deformation results in a dynamic recrystallization to eliminate the defects and become thermodynamically stable [27]. Also, it is suggested that the graphite nodules at high temperatures are cheese-liked, while at low temperature the graphite nodules become harder. The occurrence of dynamic recrystallization is due to the pileup of dislocations [16].

Moreover, due to the plastic deformation of the specimens, the graphite nodules shape is changed in a direction parallel to the applied force in comparison with the as-cast structure. The deformation process at high temperatures namely $950^{\circ} \mathrm{C}$ and $900^{\circ} \mathrm{C}$ results in changing the graphite shape from a spheroidal-like to a saucer-like shape. However, by decreasing the deformation temperature to $850^{\circ} \mathrm{C}$ as well as $800^{\circ} \mathrm{C}$, graphite with lamellar shape is observed. Therefore, the austenitic matrix containing graphite nodules are in the shape of saucers. However, after the deformation process, the graphite nodules become lamellar graphite surrounded by the pro-eutectoid ferrite phase. Similar graphite shape is also reported elsewhere [6]. Hence, the matrix surrounding the graphite nodules as well as the deformation temperature strongly affect the final shape of graphite nodules after the deformation process, as schematically presented in Figure 12. The effect of the deformation temperature on the graphite volume fraction is compared to other work [6], Figure 13. The graphite volume fraction increases by decreasing the deformation temperature of the ductile iron with $\mathrm{CE}=4.48$. However, it is detected-in ductile iron with $\mathrm{CE}=4.8$ - that the general trend of the graphite volume fraction decreases within $[800-950]^{\circ} \mathrm{C}$ by decreasing the deformation temperature. The cooling rate of the specimens with $\mathrm{CE}=4.8$ was slow (air cooled to room temperature) which might have promoted time for the diffusion of carbon atoms to graphite nodules upon cooling resulting in increasing the graphite volume fraction.

The effect of the deformation temperature on the elastic modulus of the ductile iron is given in Figure 14. It is clear that the elastic modulus of the ductile iron increases by decreasing the deformation temperature from $950^{\circ} \mathrm{C}$ to $900^{\circ} \mathrm{C}$ at the same applied strain rate. Thus, the resistance of the austenitic matrix to deformation is much higher at $900^{\circ} \mathrm{C}$. Further decrease in the deformation temperature to $850^{\circ} \mathrm{C}$ and $800^{\circ} \mathrm{C}$ results in a significant decrease in the elastic 


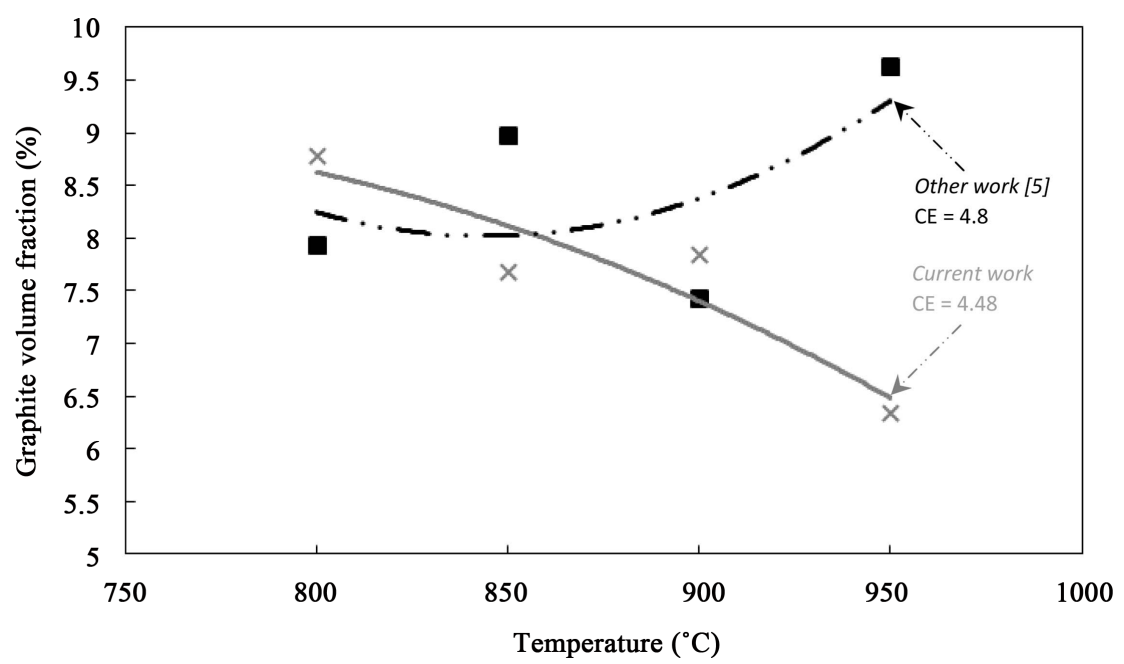

Figure 13. The effect of the deformation temperature on the graphite volume fractionin comparison with other work.

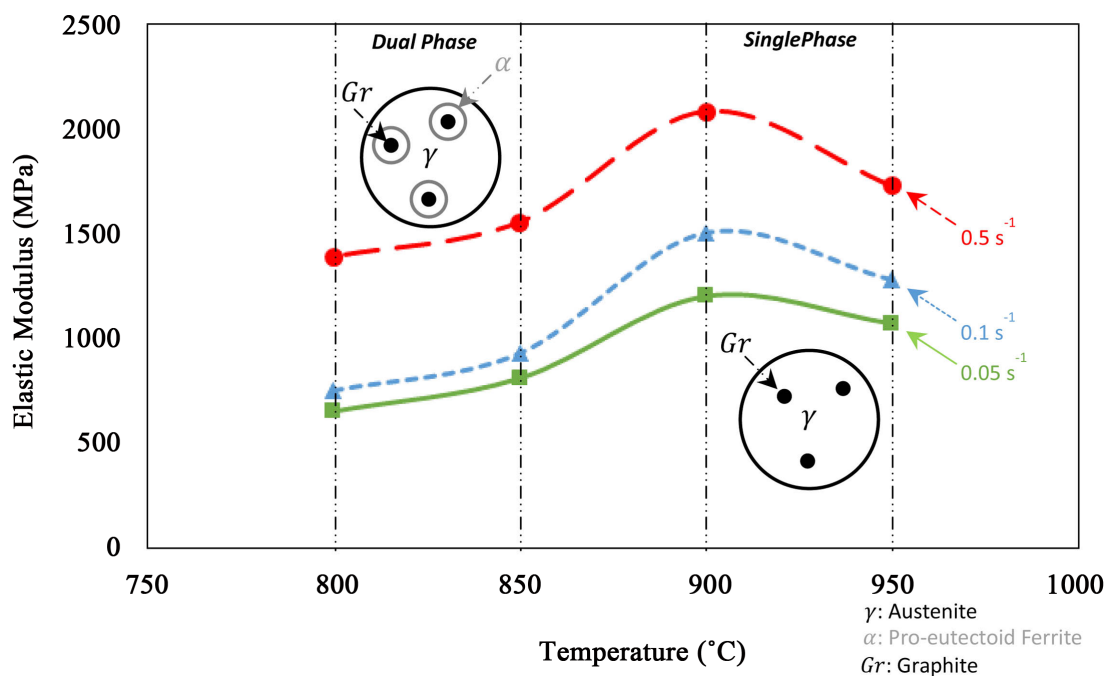

Figure 14. The effect of deformation temperature on the Elastic modulus of the ductile iron at applied strain rates of $0.05,0.1$ and $0.5 \mathrm{~s}^{-1}$.

modulus. Therefore, the resistance of the dual matrix to deformation decreases by introducing the soft pro-eutectoid ferrite phase to the matrix. Figure 15 shows the effect of the deformation temperature on the strain hardening exponent of the ductile iron at applied strain rates of $0.05,0.1$ and $0.5 \mathrm{~s}^{-1}$. The highest strain hardening exponent value is detected by deforming the ductile iron within the austenitic zone with a high strain rate of $0.5 \mathrm{~s}^{-1}$. However, the lowest strain hardening value is observed by deforming the ductile iron within the dual phase region with the same applied strain rate of $0.5 \mathrm{~s}^{-1}$. Moreover, it is clearly showed that by decreasing the deformation temperature from the austenitic region to the ferritic + austenitic region results in decreasing the strain hardening exponent [28]. Consequently, introducing the soft pro-eutectoid ferrite phase during the deformation process resulted in decreasing the strain hardening exponent. 


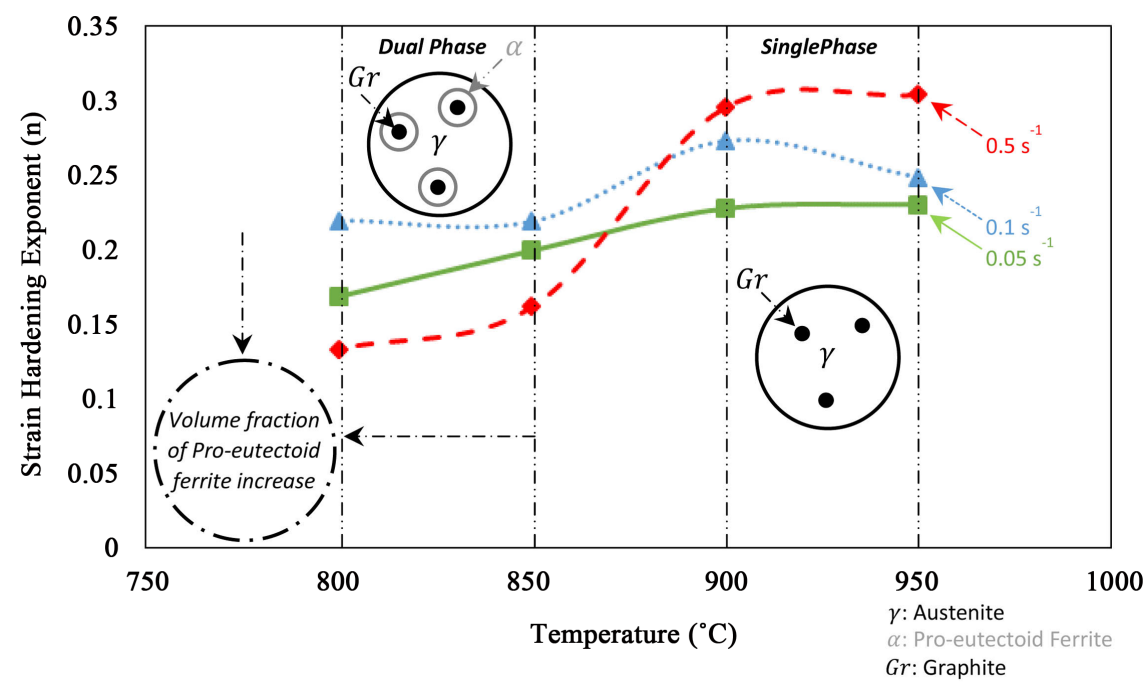

Figure 15. The effect of deformation temperature on the strain hardening exponent of the ductile iron at applied strain rates of $0.05,0.1$ and $0.5 \mathrm{~s}^{-1}$.

\section{Conclusions}

- Thermo-mechanical simulation using Gleeble System conducted on a ductile iron alloy (CE of 4.48, and Ac11 and $\mathrm{Ac} 12$ of $792^{\circ} \mathrm{C}$ and $867^{\circ} \mathrm{C}$ respectively, as detected by dilation test) applying strain rates of $0.05,0.1$, and $0.5 \mathrm{~s}^{-1}$ and varying deformation temperatures causes variation in structure and flow stress behavior as follows:

- The microstructure at deformation temperatures of $950^{\circ} \mathrm{C}$, consists of a fully martensitic matrix surrounding the graphite phase. At lower temperature of $900^{\circ} \mathrm{C}$, graphite nodules embedded in a martensitic-pearlitic matrix is detected. At these temperatures, the graphite shape changes from spheroidal-like to saucer-like shape.

- The microstructure at the lower deformation temperatures of $850^{\circ} \mathrm{C}$ and $800^{\circ} \mathrm{C}$, below Ac12, $867^{\circ} \mathrm{C}$, consists of pearlite and pro-eutectoid ferrite surrounding the graphite nodules were observed in the deformed specimens, indicating austenitic-ferritic matrix. Formation of pro-eutectoid ferrite contributes to increasing graphite volume fraction as the carbon atoms diffuse from the austenitic matrix to the graphite nodules during the ferrite formation. Within the matrix and far from the graphite nodules, fine pro-eutectoid ferrite grains were also observed. At these temperatures, the graphite shape is lamellar.

- At any strain rate applied, physical simulation results show minimum values of flow stresses at $850^{\circ} \mathrm{C}$ and $800^{\circ} \mathrm{C}$. Thus, the introduction of the pro-eutectoid ferrite to the austenitic matrix reduces the stress during the deformation process. Applying strain rates of 0.05 and $0.1 \mathrm{~s}^{-1}$, a remarkable dynamic recrystallization is observed at these temperatures. At higher temperatures of $900^{\circ} \mathrm{C}$ and $900^{\circ} \mathrm{C}$, the flow stress increase to reach maximum values, beyond which the flow stress decreases again. 


\section{Funding}

This research did not receive any specific grant from funding agencies in the public, commercial, or not-for-profit sectors.

\section{Conflicts of Interest}

The authors declare no conflicts of interest regarding the publication of this paper.

\section{References}

[1] Di Cocco, V., Iacoviello, D., Iacoviello, F. and Rossi, A. (2015) Graphite Nodules Influence on DCIs Mechanical Properties: Experimental and Numerical Investigation. Procedia Engineering, 109, 135-143. https://doi.org/10.1016/j.proeng.2015.06.223

[2] Hsu, C.-H. and Chuang, T.-L. (2001) Influence of Stepped Austempering Process on the Fracture Toughness of Austempered Ductile Iron. Metallurgical and Materials Transactions A, 32, 2509-2514. https://doi.org/10.1007/s11661-001-0040-y

[3] Rehder, J. (1965) Critical Temperature Heat Treatment of Cast Irons. Foundry, June.

[4] Norman, V. and Calmunger, M. (2019) On the Micro- and Macroscopic Elastoplastic Deformation Behavior of Cast Iron When Subjected to Cyclic Loading. International Journal of Plasticity, 115, 200-215. https://doi.org/10.1016/j.ijplas.2018.11.019

[5] Labrecque, C. and Gagne, M. (1998) Ductile Iron: Fifty Years of Continuous Development. Canadian Metallurgical Quarterly, 37, 343-378.

https://doi.org/10.1179/cmq.1998.37.5.343

[6] Qi, K., Yu, F., Bai, F., Yan, Z., Wang, Z. and Li, T. (2009) Research on the Hot Deformation Behavior and Graphite Morphology of Spheroidal Graphite Cast Iron at High Strain Rate. Materials \& Design, 30, 4511-4515. https://doi.org/10.1016/j.matdes.2009.05.019

[7] Sidjanin, L., Smallman, R.E. and Young, J.M. (1994) Electron Microstructure and Mechanical Properties of Silicon and Aluminum Ductile Irons. Acta Metallurgica et Materialia, 42, 3149-3156. https://doi.org/10.1016/0956-7151(94)90412-X

[8] Ghaderi, A.R., Nili Ahmadabadi, M. and Ghasemi, H.M. (2003) Effect of Graphite Morphologies on the Tribological Behavior of Austempered Cast Iron. Wear, 255, 410-416. https://doi.org/10.1016/S0043-1648(03)00156-X

[9] Bača, J. and Chaus, A.S. (2004) Effect of Plastic Deformation on the Structure and Properties of Cast Iron with Globular Graphite. Metal Science and Heat Treatment, 46, 188-191. https://doi.org/10.1023/B:MSAT.0000043098.43295.94

[10] Lyakishev, N.P. and Shcherbedinskii, G.V. (2001) Hot Plastic Deformation of High-Strength Cast Iron. Metal Science and Heat Treatment, 43, 421-422. https://doi.org/10.1023/A:1014883023922

[11] El-Bitar, T. and El-Banna, E. (1997) Contribution of Forming Parameters on the Properties of Hot-Rolled Ductile Cast Iron Alloys. Materials Letters, 31, 145-150. https://doi.org/10.1016/S0167-577X(96)00254-6

[12] Martínez, R.G., Torre, U., Ebel, A., Lacaze, J. and Sertucha, J. (2018) Effects of High Silicon Contents on Graphite Morphology and Room Temperature Mechanical Properties of As-Cast Ferritic Ductile Cast Irons. Part II. Mechanical Properties. Materials Science \& Engineering A, 712, 803-811.

https://doi.org/10.1016/j.msea.2017.11.051 
[13] Samuel, C. and Viswanathan, S. (2008) Transformation Kinetics and Ferrite-Pearlite Ratios in a 65-45-12 Ductile Iron. International Journal of Metalcasting, 2, 55-65. https://doi.org/10.1007/BF03355436

[14] Zhao, X., Jing, T.F., Gao, Y.W., Zhou, J.F. and Wang, W. (2004) A New SPD Process for Spheroidal Cast Iron. Materials Letters, 58, 2335-2339. https://doi.org/10.1016/j.matlet.2004.01.034

[15] Zhao, X., Jing, T., Gao, Y., Qiao, G., Zhou, J. and Wang, W. (2004) Morphology of Graphite in Hot-Compressed Nodular Iron. Journal of Materials Science, 39, 6093 6096. https://doi.org/10.1023/B:JMSC.0000041709.60100.56

[16] Zhao, X., Yang, X.-L. and Jing, T.-F. (2011) Processing Maps for Use in Hot Working of Ductile Iron. Journal of Iron and Steel Research, International, 18, 48-51. https://doi.org/10.1016/S1006-706X(11)60049-6

[17] Le Mercier, K., Watremez, M., Guerin, J.-D., Fouillaud, L. and Dubar, L. (2013) Thermo-Mechanical Behavior of Spheroidal Graphite Iron in the Austenitic Phase. Congrès Français de Mécanique, 21; 2013; Bordeaux.

[18] Holst, A., Buchwalder, A., Hollmann, P. and Zenker, R. (2019) Influence of Cooling Rate on the Microstructural Features of a Remelted White Solidified Cast Iron Surface and Its Effects on Nitriding Behavior. Journal of Materials Processing Technology, 271, 377-383. https://doi.org/10.1016/j.jmatprotec.2019.04.004

[19] Chaus, A.S. (2014) Effect of Room-Temperature Compression on Microstructure of Ductile Cast Iron Subjected to Hot Plastic Deformation. The Physics of Metals and Metallography, 115, 672-681. https://doi.org/10.1134/S0031918X14040048

[20] Chaus, A.S., Sojka, J. and Pokrovskii, A.I. (2013) Effect of Hot Plastic Deformation on Microstructural Changes in Cast Iron with Globular Graphite. The Physics of Metals and Metallography, 114, 85-94. https://doi.org/10.1134/S0031918X13010031

[21] Soliman, M., Nofal, A. and Palkowski, H. (2015) Alloy and Process Design of Thermo-Mechanically Processed Multiphase Ductile Iron. Materials \& Design, 87, 450-465. https://doi.org/10.1016/j.matdes.2015.07.159

[22] Faisal, M., El-Shenawy, E. and Taha, M.A. (2017) Thermomechanical Testing of GGG 40 Spheroidal Graphite Cast Iron Alloy. Materials Sciences and Applications, 8, 273-280. https://doi.org/10.4236/msa.2017.83019

[23] El-Bitar, T., El-Shenawy, E. and El-Meligy, M. (2017) Physical Simulation of Thermo-Mechanical Processing of Ferritic-Bainitic Dual Phase (FBDP) Steel. Materials Science Forum, 879, 495-501. https://doi.org/10.4028/www.scientific.net/MSF.879.495

[24] Samuel, C.J.P. (2010) The Effect of Copper on the Eutectoid Transformation in Ductile Iron. The University of Alabama, Tuscaloosa.

[25] Trepczyńska-Łent, M. and Dymski, S. (2005) The Outlook upon Austenitizing the Matrix of Ductile Iron. Archives of Foundry, 5, 353-364.

[26] Cavallini, M., Di Cocco, V., Iacoviello, F. and Iacoviello, D. (2011) Ductile Irons Damaging Micromechanisms: Graphite Nodules Role Investigated by Means of Image Processing Procedures. Convegno IGF XXI Cassino 2011.

[27] Huang, K. and Logé, R.E. (2016) A Review of Dynamic Recrystallization Phenomena in Metallic Materials. Materials \& Design, 111, 548-574. https://doi.org/10.1016/j.matdes.2016.09.012

[28] Kilicli, V. and Erdogan, M. (2008) The Strain-Hardening Behavior of Partially Austenitized and the Austempered Ductile Irons with Dual Matrix Structures. Journal of Materials Engineering and Performance, 17, 240-249. https://doi.org/10.1007/s11665-007-9143-y 